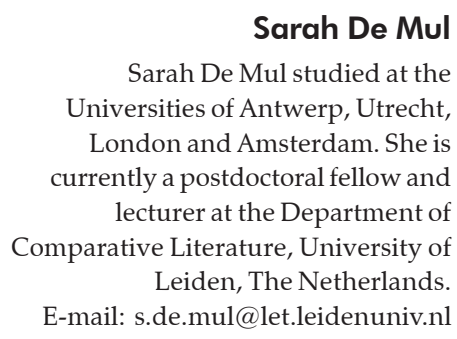

Sarah De Mul

Sarah De Mul studied at the Universities of Antwerp, Utrecht,

London and Amsterdam. She is currently a postdoctoral fellow and lecturer at the Department of Comparative Literature, University of Leiden, The Netherlands.

E-mail: s.de.mul@let.leidenuniv.nl

\section{The Congo as topos of dystopic transgression in fin-de-siècle literature}

The Congo as topos of dystopic transgression in fin-de-siècle literature

In this essay, I compare the representation of the Congo as a topos of dystopic transgression in Conrad's Heart of Darkness (1902), and in a lesser-known novel entitled Tropenwee (Tropical agony) by the Dutch author Henri van Booven, published in 1904. The idea of the Congo as a locus of degeneration will be read, not so much as a Conradian theme, but rather, as an idea that had gained wide currency throughout Europe during the fin-de-siècle period. Particular attention will be paid to some of the narrative techniques that shape this idea and the ideological assumptions it conveys. Moreover, I hope to show that degeneration as reflected by the writings under investigation is at once a colonial and anti-colonial theme, and therefore its significance requires moving beyond singular and clear-cut ideological labels. Key words: degeneration, colonialism, fin-de-siècle literature, Joseph Conrad, Henri van Booven.

\title{
Introduction
}

During the last two decades, one strand of postcolonial scholarship has emerged that scrutinizes the genealogy, discursive authority, and material conditions of possibility of Western discourses about Africa. In analogy to Edward Said's notion of Orientalism, in Blank Darkness Christopher Miller has coined the term "Africanism" for a Western tradition of representation that imposes a language of desire on the least-known part of the world, hereby exercising control over it and subsequently calling it "Africa" (Miller 1985). Miller envisions a significant role for Joseph Conrad's Heart of Darkness within this Africanist regime of representation since the novella, to quote Miller, "makes the initial perception of a discourse as 'Africanist' possible" (Miller 1985: 170).

In the wake of Miller, postcolonial scholars (e.g. Brantlinger 1988, Coombes 1994) have examined how old motifs of discovery and mystery featuring in Heart of Darkness have surreptitiously been planted on a new canvas in subsequent Western depictions of Africa and how "The Dark Continent" has continuously been represented with various tropes of degeneration, savagery, monstrosity and mystery. As travel writing critics such as Patrick Holland and Graham Huggan (2000) and Tim Youngs (2002) have suggested, since Conrad, Africa and the Congo in particular, has become the textual site of an abject and extreme, yet undifferentiated African otherness, in 
which every aspect of life presents itself as always already wrapped in metaphor and myth. Since Heart of Darkness then, the Congo has become a topos of dystopic transgression, an invented space of antagonism to the European imagination. Time and again it has been portrayed as the ultimate antidote to civilisation and believed to bring about the physical, moral and psychological downfall of both indigenous and Western subjects alike, transforming their humanity into utter barbarism.

In this essay, I will compare the representation of the Congo as a topos of dystopic transgression in Conrad's Heart of Darkness, published in 1902, and in a lesser-known novel entitled Tropenwee (Tropical agony) by the Dutch author Henri van Booven, published in 1904. Particular attention will be paid to some of the narrative techniques, which shape this idea and the ideological assumptions it conveys. The idea of the Congo as a locus of degeneration will be read, not so much as a Conradian theme, but rather, as an idea that had gained wide currency throughout Europe during the fin-de-siècle period. Moreover, I hope to show that degeneration as reflected by the writings under investigation is at once a colonial and anti-colonial theme, and therefore its significance requires moving beyond singular and clear-cut ideological labels.

The ideological ambivalence of the representation of the Congo as dystopic transgression, as I will show, is already reflected in the initial reception of both writings in their respective contexts. Conrad's text was circulated and promoted as an authoritative anti-slavery text by the Congo Reform Association, which, despite its humanitarian objectives, remained loyal to British imperial interests. Van Booven's text, in contrast, was denounced by literary critics for its anti-colonial message. Their readings subsequently prompted the author to re-confirm his support of the Belgian imperial project. That both writings were assigned such ideologically unstable meanings from the very onset is no coincidence. Even if the representation of the Congo as degeneration at first sight seems to question ideas about Western progress and the civilising mission, it is also very much reliant on them. Indeed, in portraying the Congo and its peoples as degenerating, both Heart of Darkness and Tropenwee manufacture Africanist representations which serve as a necessary corollary to confirm Western civilisation and to legitimise the need to colonise.

\section{Evolution and degeneration during the fin-de-siècle}

In 1899, the British author Rudyard Kipling published the poem entitled "The White man's Burden", which proclaimed that the guardianship over non-Western peoples is the arduous moral duty of white men. Kipling's poem captured the ethical dimension which came to define various European imperial projects around 1900 - la mission civilatrice (civilising mission) of France, de ethische politiek (the ethical policy) of the Netherlands, as well as Leopold II's rhetoric that his colonisation of the Congo was aimed to be a saving operation of the indigenous population from their Arabic 
slave masters. Around 1900, then, various imperial European nations deployed an ethical rhetoric expressing a sense of moral, racial and cultural supremacy that came to legitimise their imperial projects and commercial activities abroad. By doing so, Europeans could cherish a rather unambiguously heroic image of themselves as conquerors or righteous civilisers of the non-Western world.

With Charles Darwin's On the Origin of Species (1859), Europe had found in evolutionism an important ideology supporting such self-images. Its success illustrates the general optimism and confidence of imperial Europe during the $19^{\text {th }}$ "century of progress". At the same time, however, degeneration, as the dark side of the concept of evolution, loomed increasingly large in the European mind of the last decades of the $19^{\text {th }}$ century. The strong belief in the benefits of progress, the necessity of civilisation and the moral task of uplifting those who were not yet enlightened, also generated a widespread fear of atavism and the menace that at any single time or occasion, one's progress might be halted or obstructed, leading to degeneration and a relapse into barbarism.

The pervading atmosphere of the 1890s in Europe was increasingly one of melancholy and despair, of perceived decadence and agonizing pointlessness and disillusionment. Science contributed to this general gloom. Scientific developments, such as the law of entropy or new astronomical results, led to a view of the world which was uncontrolled by humans and dominated by laws of chance. In the shadow of evolutionary naturalism, degeneration had become a much-discussed disorder throughout fin-de-siècle Europe. As a result of the medicalisation of late $19^{\text {th }}$ century society, degeneration had infused various discussions. Theoretically the idea of degeneration has been variously elaborated by theorists such as J. A. Comte de Gobineau (1855), B. A. Morel (1857) and Max Nordau (1895) as a deficiency of the hereditary transmission system, the race or a consequence of modernity itself. By the end of the $19^{\text {th }}$ century the notion of degeneration had come to define miscellaneous phenomena - alcoholism, tuberculosis, the poor country folk - and outlined the standard of civilisation by negation (Chamberlin and Gilman 1985, Pick 1989, Kemperink 2001, Tollebeek 2003). Various scholars have pointed to its significance for domains of knowledge, such as eugenics, psychiatry and criminality, and conceptions of the city, horror, sexuality or the Gothic during the fin de siècle (Showalter 1991, Malchow 1996, Greenslade 1994, Hurley 1996, Navarette 1998, Stableford 1998, Smith 2004).

Around 1900, competition between European powers over colonial territories, especially in Africa and Asia, was growing and the first signs of nationalist sentiments in colonies such as South Africa reinforced emerging uncertainties, doubts and fears about empire. The Congo was a crucial site onto which dystopic ideas about empire were projected. A crucial event reflecting ambivalent feelings of empire was The Emin Pasha Relief held from 1886 to 1889, one of the last major European expeditions into the interior of Africa in the nineteenth century-ostensibly to the relief of 
Emin Pasha, the besieged governor of Equatoria who was threatened by Mahdist forces. Led by Henry Morton Stanley, the expedition was both celebrated for its ambition in crossing "darkest Africa", and notorious for the bloodshed and death left in its wake. The emerging testimonies and eyewitness accounts of this expedition, reporting colonial atrocities in the Congo Free State, were crucial in developing European ideas of the Congo Free State as a site of colonial degeneration.

At a time when Kipling's "The White Man's Burden" was published, writings such as Heart of Darkness and Tropenwee were being written in which the dominant ethical rhetoric of progress and civilisation was being critically examined. Reading either Heart of Darkness or Tropenwee, contemporary readers would have found portrayals of degenerating Westerners and colonial degeneration, which posed an opposite to the ethical rhetoric supporting empire dominant at the time. However, while providing a counter-discourse to the discourse of civilisation dominant in the public domain, writings such as Heart of darkness and Tropenwee are also very much complicit in reproducing some of the stereotypical ideas of the Congo and the Congolese legitimising European occupation at the time. While both texts incorporate fears of colonial degeneration, making visible the very dark sides of progress and civilisation, at the same time, they also reconfirm existing reservations about foreign climates and peoples that allegedly contaminate Westerners. This suggests that labels such as "colonial" or "anti-colonial" fall short in grasping the complex ways in which Conrad's and Van Booven's texts are subverting, while simultaneously also reconfirming prevalent European conceptions about the Western self and the Congolese other.

\section{The Congo as dystopic transgression in Heart of Darkness and Tropenwee}

Heart of Darkness is an ambivalent fictional text, a duplicitous representation riven by the contradictions lying at the heart of the colonial project. Chinua Achebe (1978) has influentially read the novella as a condemnation of the evil of imperial exploitation, one that is at the same time strangely unaware of the racism it perpetuates. The role of Conrad's novella in the postcolonial project has been variously described, defended and challenged by many interlocutors (e.g. Blake 1982, Hawkins 1982, Watts 1983). Productive of interpretative possibilities and contradictions, Heart of Darkness has been commented upon extensively by renowned postcolonial scholars - from Chinua Achebe (1978) and Edward Said (1993) to Homi Bhabha (1994) and Gayatri Spivak (2002) - who have collectively made the text central to any study of European imperialism in Africa as an imaginary enterprise. It is however not my purpose here to interrogate, or even fully enter, that debate. Instead, adopting the theme of the Congo as dystopic transgression as an analytical lens, I intend to seek ways in which the complex and Janus-faced phenomenon of European imperialism can be grasped by comparatively focusing on two individual texts reflecting local discussions and ide- 
ologies of European empires, as well as intra-European overlaps and exchanges, which have come to shape them.

Joseph Conrad was born in Poland in 1857 . His childhood ambition to visit central Africa was realised in 1889 when Conrad contrived to reach the Congo Free State. He became captain of a Congo steamboat, and the atrocities he witnessed and his experiences informed his most acclaimed and ambiguous work, Heart of Darkness. Henri van Booven, was born in the Dutch city of Haarlem in 1877. Today he is mainly remembered as the first biographer of the acclaimed Dutch author Louis Couperus (Booven 1982). Van Booven travelled to the Congo Free State in 1898 - following Conrad's footsteps nine years later. Soon however he was infected by malaria and was forced to return home after one year. Like Conrad, Van Booven kept a diary of his travel experiences, which would provide the basic material for his novel Tropenwee.

Both writers travelled to the Congo Free State during the last decade of the nineteenth century, that is, during the period when the humanitarian disaster that was taking place in Leopold's Congo became an object of critique throughout Europe. Published in 1902, Heart of Darkness had only just been published when the British House of Commons passed a resolution about the Congo, charging the British diplomat Roger Casement to make a formal inquiry into the situation in 1903. During his stay in the Congo, Conrad became acquainted with Roger Casement, whose renowned Congo Report detailed the abuses suffered by the indigenous population.

Van Booven's Tropenwee was published in 1904, in the same year when the Casement Report was published. The Report soon led to an international anti-Congo protest campaign. In March of that year, the Congo Reform Association was set up in London. Founded by Roger Casement and Edmund Dene Morel, The Congo Reform Association exposed gross and rampant abuses of labour by public servants in King Leopold II of Belgium's Congo Free State and eventually catalysed the cessation of the Congo Free State when it became a Belgian state colony in 1908.

Heart of Darkness and Tropenwee describe a journey inland on the Congo River, which runs parallel to an intensification of dismay, disaster and doom, qualifying both the representations of the African surroundings as well of the colonial protagonists. Heart of Darkness builds up towards an encounter in the interior between Marlow and Mr Kurtz, after which the former turns "to the wilderness" (89) and the latter cries out "the horror! the horror!" (106), before eventually dying. In Tropenwee, the destination of the protagonist's journey, a Dutch trading station in upper Congo where he is sent off to work, is never reached. Instead, the plot comes to its climax prematurely, when, suffering from malaria and struggling for his life on board of the ship, the protagonist is forced to return home without having reached his destination.

Regarding its formal composition, the narrative of Heart of Darkness is much more complex and layered than Tropenwee. Heart of Darkness, as is well-known, is textually composed by embedded narratives which resonate and enter into dialogue with 
various contradictory ideas and notions about empire prevailing at the time, as rendered by at least three focalisers - Mr Kurtz, Marlow and an anonymous listener to Marlow's narrative. In Heart of Darkness, Kurtz is portrayed as the eloquent and expressive man who talks, but his speech is hardly ever textualised, except for his renowned last words, which refer to an unspecified agony. Most of Kurtz's words are rephrased in the words of others, for instance by Marlow. Marlow, however, is a sailor, not a man of many words, especially not when it concerns his own experience. Rendering his travel experience in the Congo, he continuously leads the attention away from his personal experience. Marlow's narrative is subsequently re-narrated to the reader by an anonymous listener to his story.

Multiple interlocutors, voicing other people's speech, mediate the narrative. Both the forms and the plurality of the standpoints make it often impossible to discern the extent to which a given view or discourse (for instance about the black population) is sincerely believed or ironically rehearsed, whether a stance is honestly formulated or critically parodied. The device of narrative framing to a certain extent creates distance and prevents readers from empathising fully with one character, view or belief. This narrative complexity plays an important role in reinforcing the ideological ambivalence by means of which the idea of the Congo as a topos of dystopic transgression is depicted.

Tropenwee is a more traditionally and straightforwardly linearly constructed narrative. Van Booven adopts an omniscient narrator to render a third-person narrative of the geographical and psychological journey of a Dutch protagonist named Jules. Jules - nicknamed "The White One" from the moment he crosses the equator-is both the one undertaking the journey as well as the one around whom the account of degeneration centres. He is the focal point of attention and, in a sense, embodies the experiences of both Kurtz and Marlow in Heart of Darkness. Although rendered in the third person by an omniscient voice, Tropenwee is akin to the travel witness account, which is traditionally accompanied by a specific horizon of expectations including notions of ethnographic authority, authenticity and experiential truthfulness. In line with the narrative structure, Tropenwee is principally concerned with the experiences, impressions and sensations of the main protagonist. This connects the representation of the Congo Free State as a site of colonial degeneration much more clearly to the personal and the subjective experience of a single figure with whom readers are inclined to empathise.

At the same time, however, the ethnographic authority of the protagonist Jules is to a certain extent undercut by his own subjectivity. Borrowing from the literary tradition of decadentism (derived from the Latin de-cadentia meaning degeneration), Van Booven portrays the masculine protagonist as a rather weak and highly sensitive, if not sentimental figure - almost as the embodiment of a crisis of conventional epicheroic masculinity, the latter ideal clearly being upheld by Marlow. To a certain extent 
the apocalyptic pathos with which Jules's account of his illness and struggle for survival is conveyed, challenges the alleged authority and authenticity of his impressions of the Congo. In other words, in a sense one cannot help wondering whether the perception of the Congo as a topos of dystopic transgression is not related to Jules' private inclination towards the romantic or the decadent - as exemplified by his numerous surreal visions and hallucinations - than conveying the 'truthfulness' the genre of travel literature conventionally induces. As a travel narrative interwoven with decadent dimensions, Tropenwee thus undercuts its own ethnographic authority over the representation of the Congo as a topos of dystopic transgression.

In its formal simplicity, Tropenwee produces a representation of the Congo Free State as utter dread and total horror, an effect similar to the one produced by the complex narrative layering of Heart of Darkness. Conrad deploys language and narrative economically, poetically as it were, exploiting the suggestive potential of restricted amounts of language to achieve a maximum effect of calamity and uncertainty. Heart of Darkness is, of course, a novella. Van Booven, by contrast, achieves a similar effect by a more epic deployment of language and narrative. In Tropenwee, disaster slowly creeps into the reader's mind as a result of a relentless sequence of scenes and images in which catastrophe after catastrophe occur, and which are conveyed in grandiloquent sentences and extensive metaphors.

By token, both Heart of Darkness and Tropenwee bring home to the reader that the Congo Free State induces the blurring of any clear-cut distinctions between reality and dream. However, while Heart of Darkness in many instances hints at the dreamlike, nightmarish circumstances in which Marlow finds himself, ${ }^{1}$ Tropenwee describes Jules experiencing one nightmare after another death vision. Heart of Darkness deploys "the terrific suggestiveness of words heard in dreams, of phrases spoken in nightmares" (Conrad 1963: 95) to convey the Congo as a site of transgression, while Tropenwee conveys, rather than suggests, these words explicitly and extensively, the accumulation of which, serves to obtain a similar effect.

In both Tropenwee and Heart of Darkness ominous flash-forwards are deployed to announce the ultimate dystopic culmination of the plot. For instance, during their journey inland, both Marlow and Jules hear agonizing stories about colonial life upstream, which is in both cases the protagonist's final destination. They hear about white men upstream having gone mad, committing suicide and being involved in corruption. In Heart of Darkness, Marlow hears about Mr Kurtz long before he finally meets him. The manager tells him: "Mr Kurtz was the best agent he had, an exceptional man, of the greatest importance to the Company" (Conrad 1963: 32). Gradually Marlow finds out that the eloquent and admired Kurtz had retreated in the interior and had been raiding the entire district for ivory. In Tropenwee, Jules similarly hears among the many stories of degenerate employees upstream, one story about "one of the brightest of the company" (Van Booven 1933: 93) who had for years been involved 
in the rubber trade up stream. When the company had failed once to supply him with provisions, he started to buy goods from the indigenous people, stole rubber from trading companies and returned with the profit to Europe.

In addition to the gloomy stories that Marlow and Jules hear about their destination, the notion that the protagonists are descending into disaster and dismay resides in the impressions of the natural surroundings that are forced upon them during their journeys. In Heart of Darkness, for instance, "the wilderness itself [is] with an air of brooding over an inscrutable purpose" and "the stillness of life did not in the least resemble a peace. It was the stillness of an implacable force brooding over an inscrutable intention" (Conrad 1963: 87, 48). In Tropenwee one reads ominous descriptions of the surroundings such as: "These depths, these spaces resembled wide entries into a mysterious place in the world, inhabited by anger and the most unthinkable cruelty. The white one looked at them with anxiety and terror for such vast and overwhelming menace" (Van Booven 1933: 57). "Again he felt the agony for the unknown, the vague feeling of fear for strange things that may happen [...] something incomprehensibly fearful and inscrutable that was waiting there in the South" (Van Booven 1933: 22). ${ }^{3}$

It is in fact hard to underestimate how both Heart of Darkness and Tropenwee emphasise associations between the Congolese landscape (e.g. the trees, the night, the river), its mystery (the surroundings are "impenetrable", "incomprehensible", "dense", "dark", "concealed" and "secretive") and the terrifying qualities ascribed to it. As one can gather from such fragments, the dreadful downfall of the protagonists is anticipated by emphasising the enigmatic and mysterious nature of their surroundings, which announces the unfortunate unfolding of forthcoming events. Paradoxically enough, such flash-forwards hint at the negative development of the protagonists' journeys, without telling us what precisely is going to happen. In the hazy nature of such allusions, the idea of dystopic transgression itself is reinforced.

The anticipation of the dystopic unfolding of events is also firmly tied to a conception of the Congolese space - the river, climate, jungle - as an extremely active and alien force of destruction and annihilation. Marlow observes that it is: "As if Nature herself had tried to ward off intruders; in and out of rivers, streams of death in life, whose banks were rotting into mud, whose waters, thickened into slime, invaded the contorted mangroves, that seemed to writhe at us in the extremity of an impotent despair" (Conrad 1963: 62). In Tropenwee too, the protagonist's physical and mental collapse seems to be principally wrested by the surroundings in which he finds himself: "A wide fear expanded to an abhorrent despair. He was alone, alone against the cruel hostility of the destructive landscape that came from everywhere to bring total annihilation" (Van Booven 1933: 20). ${ }^{4}$

Furthermore, neither in Heart of Darkness nor in Tropenwee, black characters have individual names or personal characteristics. Conrad depicts them, for example as 
"black shadows of disease and starvation, lying confusedly in the greenish gloom" (Conrad 1963: 24). Henri van Booven (1933: 45) talks about "a walking chain of black naked wretched" (een wandelende keten van naakte, zwarte rampzaligen ). In many instances, the indigenous at once appear and disappear before the protagonists; they blend in and pop out of their surroundings. The impression is to a certain extent created that they literally belong to nature (instead of civilisation). Conrad (1963: 24) says that "black shapes crouched, lay, sat between the trees, leaning against the trunks, clinging to the earth, half coming out, half effaced within the dim light, in all the attitudes of pain, abandonment, and despair." Van Booven (1933: 31) says that a group of black rowers appeared to "resurrect squatted from the soil" (schenen als gehurkt uit den bodem te herrijzen). Such anonymous and dehumanised depictions of the local multitudes seem to suggest that the Congolese are an integral part of the destructive décor in which the protagonists find themselves.

Hence at stake in both writings is a psychological interiorisation of African travel, which is firmly tied to racial conceptions of the Congolese as a foreign, wild, natural race and geographical notions of the Congolese interior constructed as alien, fearsome, mysterious and ultimately destructive. Ideologically, such conceptions of the Congolese peoples and surroundings are inherently ambivalent. On the one hand, presented as an uncivilised, chaotic and mysterious space, the Congo provides the ultimate legitimisation of European colonialism and the installation of civilisation. On the other hand, the conception of the Congo as a powerful, destructive force also troubles European self-confidence and questions Europe's ability to complete the colonial project it had begun.

This inherent ideological ambivalence of the idea of dystopic transgression is also illustrated by the deployment of metaphors and imagery. In the composition of the crescendo towards ultimate degeneration, both Heart of Darkness and Tropenwee deploy a wide array of ambiguous images and symbols of darkness and light (e.g. shadow, fire, gloom, fog, lightning, candles) and metaphors of black and white in various shades and intensities. Whereas in Heart of Darkness Marlow refers to European colonial officers as "emissaries of light" (Conrad 1963: 18), in Tropenwee, references to the protagonist's first name, "Jules" are replaced by the metonym de witte (The White One) as soon as he crosses the equator.

Associations between Europe whiteness, (en)light(enment), purity and civilisation soon become blurred and troublesome. As the narrative proceeds, colonial presence in the form of characters or machinery is, in fact, all but light or white. Colonial servants are in various ways portrayed as being in a negative state of relapse, both physical - with yellow skin, hollow eyes, and undernourished - and psychological. They are depicted with epithets of idleness, drunkenness, insanity, indifference or cruelty. Stations along the river, all in various states of decay, show nothing of a thriving industrial commerce. The railway being built at Matadi is described, not as a 
proud symbol of European industrialisation and technological know-how, but in a bleak register of degeneration by Van Booven (1933: 47) - "ethereal iron skeleton", "dark, carbon-like, dusty" (Ijle metalen geraamte, donker, roetachtig, vuil bedwalmd ) - as well as by Conrad (1963: 22) - "as dead as the carcass of some animal", "decaying machinery", "a stack of rusty rails." The blurring of the association between enlightenment and Europe on the one hand, and dark barbarism and the Congolese space on the other hand is also illustrated by the fact that black figures are often described as possessing qualities or external features connected to whiteness, such as their teeth ("the glistening of their pure teeth" de glinstering van hunne gave tanden in Tropenwee) or eyeballs ("the white of their eyeballs glistening" [Conrad 1963: 20]) in Heart of Darkness.

In both Heart of Darkness and Tropenwee, however, even though the narrative proceeds to build up towards an ultimate representation of dystopic transgression, this ultimate form of degeneration itself is never represented. In the case of Heart of Darkness, when Marlow finally reaches his final destination and encounters Mr Kurtz, a sense of belatedness is brought home to us. After all, Mr Kurtz's experience of the Congo has come to an end as he is already lying on his deathbed when Marlow finds him. Kurtz, the man who Marlow came to know through stories by eyewitnesses as an eloquent man of words, is finally only able to hint at a vague signified by means of the phrase "the horror" and no more. By doing so, it remains unclear whether Kurtz refers to his own degradation, to the horrific tragedies he has witnessed or a combination of the two.

In the case of Tropenwee, Jules' severe illness prevents him from reaching his final destination upstream. His physical inability to proceed with his journey also creates a sense of untimeliness regarding the representation of dystopic transgression. Together with Jules, the reader returns back home prematurely and is left without the ultimate portrayal of dystopic transgression to which the novel in so many ways alluded and anticipated. By doing so, the reader, together with Jules only hears many appalling stories about the Congolese interior as a site of dystopic transgression, but the definitive representation of dystopic transgression remains evasive to both Jules and the reader.

\section{The Congo as dystopic transgression and its ideologically unstable reception}

Heart of Darkness and Tropenwee clearly seem to be interwoven with the discourse of degeneration in Britain, if not in the whole of Europe, projected on the Congo and its genocide of the native population. As we might recall, both writings were published at the very moment that the Congo Reform Association was being established to lead an international anti-Congo campaign. With its close connections to writers and journalists, the Congo Reform Association interpreted testimonies and eyewitness 
accounts of colonial atrocities in the Congo Free State to suit its anti-slavery image. In 1909, Edmund Dene Morel discussed the Congo atrocities in a letter to author Arthur Conan Doyle and wrote that Heart of Darkness was the "most powerful thing ever written on the subject" (in Hawkins 1981/1982: 80). This indicates the extent to which Conrad's novella was embraced by the Congo Reform Association as an authoritative anti-slavery critique of the Congo Free State. Even though Conrad did not agree with the liberal ideology of the Congo Reform Association, he did consent in having some of his writings used for the purpose of its cause. The connections and meetings between Roger Casement and Joseph Conrad are also well documented.

Reading Heart of Darkness as an anti-slavery critique, The Congo Reform Association explicitly focused on how the novella rendered an account of the horrific realities occurring in the particular colony under the sovereignty of the Belgian King Leopold II. As Rob Burroughs (2006: 7) has noted, one of the implications of this reading was that "though the slaveries might have suggested to a minority the fundamental ills of colonialism per se, to a majority of Britons they represented the wrongdoings of others." In other words, for the most part, Conrad's novella was read as an allegation against Belgian colonizers only. In the process, Britain managed to assuage its own historical involvement in the colonial violence taking place in the Congo Free State.

The Congo Reform Association predominantly drew on reports and accounts written in the English language and on the support of British authors, from Arthur Conan Doyle and Mark Twain to Joseph Conrad. Eyewitness reports of atrocities written in other languages were seldom translated (Burroughs 2006: 19). Borroughs argues that the Congo Reform Association's consultation of its own institutes and witnesses over other nations is suggestive of the national aspirations determining the movement. Moreover, it is worthwhile noting that humanitarian critics of empire in the British context, such as Casement and Morel, were liberals that had in fact never abandoned their core belief in the value of imperialism for free trade. They were supportive of the extension of Britain's informal interests in territories such as the Congo Free State, which were officially in possession by other empires. Hence, their struggle for the eradication of slavery in Leopold's Congo was inseparable from the cessation of the trading monopoly of Leopold II for economic purposes. Seen in the context of the Congo Reform Association then, Heart of Darkness circulated as an antislavery message, one that was at the same time used for the liberal imperial ends of the founders of the movement. This shows that Heart of Darkness was susceptible to both colonial and anti-colonial, or anti-slavery readings as soon as it was published.

Tropenwee, a novel which by now has been almost entirely forgotten, was immensely popular at the time of its first publication in Belgium and the Netherlands. It was reprinted no less than eighteen times during the first half of the twentieth century. During this period, critics such as Raoul Raes (1943) and Arthur Verthé and Ber- 
nard Henry (1963) (whose literary criticism is with hindsight remarkably supportive of colonial ideologies) have criticised the novel for the allegedly anti-colonial message it conveys. Because of such criticism, Van Booven felt inclined to put his ideological record straight in an unpublished essay written in 1951. In this essay, Van Booven reacts against ideological readings of his novel. He asserted that Tropenwee has nothing to do whatsoever with this or that method of colonising, neither with class struggle. Voicing the decadent notion that art and morality were distinct realms and that art was completely autonomous and free of ethics, Van Booven (1951) instead emphasises that the novel is:

[...] from the beginning till the end, only a description of the experiences in the tropics of one protagonist and this only vaguely too. The protagonist is a "type", by ancestry and disposition sensitive and impressionable, characterised by a sharp visual memory but also by an indefinite love of nature, ceaselessly so, even when he nearly perishes in the burning sun of the tropics. ${ }^{5}$

After rebutting the anti-colonial readings of his novel, Van Booven ends his essay with expressing his admiration and support of imperialism as a whole and Belgian colonialism in particular, hence reinforcing the colonial spirit his criticizers had accused him to lack. Since its publication, then, Van Booven's novel on the Congo as dystopic transgression has triggered diametrically opposed readings that suggest that clear-cut ideological labels fall short in understanding the literary representation of degeneration.

Fiction about the Congo as a site of dystopic transgression during the fin-desiècle, such as Heart of Darkness and Tropenwee, adopt ambivalent narrative techniques that reinforce this ideological haziness. Portrayals of degenerate colonial servants may be read as questioning righteous and ethical justifications of empire, whereas 'barbaric' depictions of the Congolese surroundings can be taken to support 'the White Man's Burden'. The narrative layering and multivocality of Heart of Darkness and the alternation between travel writings's experiential truthfulness and a decadent gesturing towards the subjective-affective and the impressionistic in Tropenwee also serve to attribute colonial degeneration a political dimension which is inherently volatile. Moreover, both texts create a sense of untimeliness in witnessing colonial degeneration in the Congo. Marlow comes too late to observe Kurtz' degenerate activities and Jules prematurely returns without reaching the scene where degeneration is taking place. Such devices for ever postpone the possibility of attributing any stable political meaning to the idea of the Congo as dystopic transgression, while at the same time the idea remains always indistinctly alluded to and conveyed.

Hence, fiction about the Congo as a site of dystopic transgression during the finde-siècle, such as Heart of Darkness and Tropenwee may be considered a necessary corollary to confirm the colonial idea of Western civilisation and progress, one that ambiv- 
alently manufactures Africanist representations, even as it can be read as demystifying them. They present a corollary to the dominant discourse of Western civilisation that is reliant on, even as it questions, some of the European self-images and images of its others dominating the imperial European imagination of the fin de siècle.

Notes

1 "I remained to dream the nightmare out to the end. [...] There were moments when one's past came back to one, as it will sometimes when you have not a moment to spare to yourself; but it came in the shape of an unrestful and noisy dream, remembered with wonder amongst the overwhelming realities of this strange world of plants, and water, and silence. [...] I positively hoped, that my aspect was not so - what shall I say? - so - unappetizing: a touch of fantastic vanity which fitted well with the dream-sensation that pervaded all my days at that time". (Conrad 1963: 112).

2 All translations are mine. "Deze diepten, deze ruimten geleken wijde ingangen tot een geheimzinnige plek in de wereld, waar de boosheid en de ongedachtste wreedheid huisden. De witte keek er naar met onrust en ontzetting voor zóóveel matelooze, grootsche onheilspellendheid" (Van Booven 1933: 57).

3 "Weer voelde hij de beklemming om het onbekende, het vage gevoel van vrees voor vreemde dingen die zouden kunnen gebeuren, [...] iets onbegrepen angstig geheimzinnigs, dat daar in het Zuiden te wachten lag" (Van Booven 1933: 22).

5 "Een wijde angst zette zich uit tot een afschuwelijke wanhoop. Hij stond alleen, alleen tegenover het wreedvijandige van deze vernietigende natuur, die zich van overal opzette tot volkomen verdelging [...]" (Van Booven 1933: 88).

6 "van begin tot einde uitsluitend beschrijving van de ervaringen in de tropen van slechts één hoofdpersoon, en deze nog maar vaag. Het is een 'gestalte', door afstamming en aanleg sensitief en impressionabel, begaafd niet alleen met een scherp visueel geheugen, maar ook met een onbegrensde liefde voor de natuur, die geen ogenblik verflauwt, zelfs niet wanneer hij in het zonnevuur der tropen haast bezwijkt" Van Booven (1951: 2-3).

\section{Works cited}

Achebe, Chinua. 1978. An Image of Africa. Research in African Literatures, 9 (Spring): 1-15.

Bhabha, Homi. 1994. The Location of Culture. London \& New York: Routledge.

Blake, Susan L. 1982. Racism and the Classics: Teaching Heart of Darkness. College Language Association Journal, 25: 396-404.

Booven, Henri, van. 1933 [1904]. Tropenwee. Amsterdam: Maatschappij voor goede en goedkoope lectuur. . 1951. Over het ontstaan van Tropenwee. Unpublished typescript. Private Archive Christiaan van Vuure, 1-11.

. 1982 [1933]. Leven en werken van Louis Couperus. Met een nawoord van F. L. Bastet. 's Gravenhage: BZZTôH.

Burroughs, Robert. 2006. Britain's Travelling Witnesses: Narratives of the New Slaveries 1884-1916. Nottingham Trent University. Unpublished Ph.D. dissertation.

Brantlinger, Patrick. 1988. Rules of Darkness. British Literature and Imperialism, 1830-1914. Ithaca, London: Cornell University Press.

Coombes, Annie E, 1994. Reinventing Africa. Museums, Material Culture and Popular Imagination in Late Victorian and Edwardian England. New Haven, London: Yale University Press.

Conrad, Joseph. 1963 [1902]. Heart of Darkness. Robert Kimborough (ed). New York: Norton.

Gobineau, J. A. Comte de. 1953 [1884]. Essai sur l'inégalité des races humaines. Paris: Didot.

Greenslade, W. 1994. Degeneration, culture and the novel 1880-1940. Cambridge \& New York: University Press.

Hawkins, Hunt. 1981/1982. Joseph Conrad, Roger Casement and the Congo Reform Movement. Journal of Modern Literature, 9 (1): 65-80. 
1982. The Issue of Racism in Heart of Darkness. Conradiana, 14 (3): 163-71.

Holland, Patrick \& Graham Huggan. 2000. Tourists with Typewriters. Critical Reflections on Contemporary Travel Writing. Ann Arbor: University of Michigan.

Hurley, Kelly. 1996. The Gothic Body: Sexuality, Materialism, and Degeneration at the fin de siècle. Oxford \& Cambridge: Cambridge University Press.

Malchow, H. L.1996. Gothic Images of Race in Nineteenth-Century Britain. Stanford: Stanford University Press.

Miller, Christopher L. 1985. Blank Darkness: Africanist Discourse in French. Chicago: University Press.

Morel, B. A. 1857. Traité des dégénérescences physiques, intellectuelles et morales de l'espèce humaine et des causes qui produisent ces variétés maladives: atlas. Paris: Ballière.

Navarette, Susan J. 1998. The Shape of Fear: Horror and the Fin de Siecle Culture of Decadence. Lexington: University Press of Kentucky.

Nordau, Max. [1895]. Degeneration and Evolution. I. A reply to my critics. The North American Review, 161 (464). < http://cdl.library.cornell.edu/cgi-bin/moa/sgml/moa-idx?notisid=ABQ7578-0161-11> Accessed: 01.11.2008

Raes, Raoul. 1943. Kongo in de Nederlandsche letterkunde. University of Antwerp. Unpublished M. A. thesis.

Said, Edward. 1993. Culture and Imperialism. New York: Knopf.

Showalter, Elaine. 1991. Sexual Anarchy: Gender and Culture at the Fin de Siècle. London: Bloomsbury.

Smith, Andrew. 2004. Victorian Demons: Medicine, Masculinity and the Gothic at the Fin-de-siecle. Manchester: Manchester University Press.

Spivak, Gayatri Chakravorty. 2003. Death of a Discipline. New York: Columbia University Press.

Stableford, Brian. 1998. Glorious Perversity: The Decline and Fall of Literary Decadence. San Bernardino: The Borgo Press.

Verthé, Arthur and Bernard, Henry. 1963. Geschiedenis van de Vlaams-Afrikaanse letterkunde. Leuven: Davidsfonds.

Watts, Cedric. 1983. 'A Bloody Racist': About Achebe's view of Conrad. Yearbook of English Studies, 13: 196-209.

Youngs, Tim. 1994. Travellers in Africa. British Travelogues 1850-1900. Manchester: Manchester University Press.

2002. Africa/The Congo: The Politics of Darkness. Peter Hulme \& Tim Youngs (eds). The Cambridge Companion to Travel Writing. Cambridge: Cambridge University Press, 156-72. 